\title{
ART, MODERNITY, AND SCEPTICISM
}

\author{
A B S T R A C T
}

The Paper deals with the problem of relation between art and modernity-our main thesis is that the artist in an age of modernity deals with the problem of privacy. The notion of privacy is used in Wittgenstein's sense, as analogy to his theorization of fantasy of private language. His concept of private language is a description of withdrawal of ordinary language from the process of inter-social relations and its everyday use; in that way, private language fantasy is a kind of scepticism. Regarding the fact that the notion of epistemological scepticism is connected to the idea of modernity (Descartes', Hume's, Lock's modern sceptical subject), the main problem for modern artist is how to transcend the condition of radical scepticism, i.e. the condition that Stanley Cavell, in Wittgenstein's sense calls "metaphysical isolation". 
The Incredulity of St. Thomas is a canvas painted by Caravaggio in 1601-2; it shows a popular religious scene from the Gospel of St. John: St. Thomas was one of the apostles who missed Christ's arrival after the Resurrection. Expressing his doubt regarding the Resurrection of Christ, according to the Bible, St. Thomas stated: "Unless I see the nail marks in his hands and put my finger where the nails were, and put my hand into his side, I will not believe it.' (John 20:25) A week later, Christ appeared again and Thomas, having examined his wounds, lost all doubt; the story ends with the following words by Christ: "Because you have seen me, you have believed; blessed are those who have not seen and yet have believed' (John 20:21). The scene is relatively frequent in Western art history, but what a number of interpreters have noted is that Caravaggio's depiction differs in many respects from the usual treatment of this Biblical story: standing out is Caravaggio's typicall dramatic approach, light and shadow, as well as pronounced "corporeality' of the scene, with the rough fingers of the saint "penetrating' Christ's wound, as well as the absence of the usual haloes above Christ's head and those of the apostles. The painting's theme is obviously the scepticism of St. Thomas; of course, interpreters have understood this as religious scepticism and transcending it by finding "proof' for a return to faith. Nevertheless, it seems to me that what essentially separates Caravaggio's canvas from other treatments of this scene in the history of art is an entirely different form of scepticism that is no longer necessarily related to religious meta-narratives. My reading of scepticism in Caravaggio's painting stems from problematizations of modern sceptical doubt, which was most thoroughly treated by Ludwig Wittgenstein in his Philosophical Investigations: in his interpretation of Wittgenstein's text, Stanley Cavell asserts that the main problem of this book is what he calls "other-minds scepticism'.

Other-minds scepticism is a form of scepticism about another person, the doubt regarding the feasibility of cognising another person. Hiding behind this problematic is a specific social constellation outlined by the modern age: in the classical, Christian-feudal historical constellation, social relations were mediated by 'external' criteria (God, religion, tradition, the ruler's absolutist authority, and the like), which supported the social structure as an "organic' whole and rendered the social relations fixed, stable, and determined a priori. Wittgenstein and Cavell's argument is that the modern age brought forth a crisis of these a priori criteria, on the basis of which individuals, through language, construct inter-social relations. As Cavell asserts, these criteria are not mere conventions that an individual or a collective directive might change; but equally, they are not timeless and reflect no truths that have been given once and for all. Quite to the contrary, these criteria are subject to change, 
determined by what Wittgenstein calls "forms of life', and as such, participate in that life's 'flexible inflexibilities': they are as resistant and open to change as are the broader patterns of human behaviour that surround them. ${ }^{1}$ Accordingly, there is no external instance that might guarantee our mutual agreement or consensus in language - at all times we must be prepared for the possibility that any claim regarding mutuality in language may be refuted. ${ }^{2}$ In its modern form, scepticism is thus always a fantasy of privacy and a private language; my claim is that Caravaggio, as the first truly modern author, treated not religious scepticism, but the modern fantasy of closing off into a language of one's own, that is, "other-minds scepticism'. As Wittgenstein put it himself: "One human being can be a complete enigma to another'; the "other' as an enigma and the "self' as an enigma for the other, and not the relationship between the "I' and God, is the problem that drove Caravaggio's art, for the first time in the history of Western art.

In their book Caravaggio's Secrets, Leo Bersani and Ulysse Dutoit analyse Caravaggio's (self-)portraits (e.g. Bacchino Malato, 1593 and Boy with a Basket of Fruit, 1593-94) and assert that beneath their ostensible exhibitionism, these portraits in fact exhibit opacity, resting on the tension between erotic address, seduction, and self-hiding, withdrawal, retreat from the gaze of the other, i.e. the observer. In Caravaggio's paintings, the body thereby becomes an enigma, a closed entity that suspends the mutuality of inter-social relations; Caravaggio's portraits of young men gaze at us but at the same time also retreat from our gaze. On Caravaggio's canvases we thus encounter bodies that fail (or do not want) to be "bodies that matter":

"What seems to interest Caravaggio more is a body at once presenting and withdrawing itself - a somewhere enigmatic body. The distinction between nonerotic and erotic address might be, not that the latter solicits greater intimacy or fewer barriers between persons, but rather that it solicits intimacy in order to block it with a secret. Erotic address is a self-reflexive move in which the subject addresses another so that it may enjoy narcissistically a secret to which the subject itself may have no other access. The subject performs a secret, which is not at all to say that he or she has any knowledge of it."'3

In a relatively similar manner, Michael Fried offers a detailed analysis of the formal procedures Caravaggio used in his paintings: from using mirrors to painting live models; he also notes that due to posing for long periods of time, his models often 'exhibit' boredom, that is, Fried argues that in his art Caravaggio pursued a sort of annihilation of expression. For instance, The 
Crowning with Thorns from 1604 or 1607: note the expression on Christ's face, which is quite close to that from the painting with St. Thomas - is this an expression of pain and physical suffering? Or, rather, one of complete spiritual absence, spiritual void, as if there were no 'internal life' in Christ at all that might manifest itself on his face? Similarly interesting is the gaze of the male figure in the top left corner: we might expect his gaze to be fixed on the back of Christ's head, the place where he is hammering in the crown of thorns with a bamboo stick; however, his gaze is lost in the undefined space between Christ's right shoulder and neck. This gaze thus becomes "empty', suggesting a similar kind of spiritual annihilation as Christ's gaze does. The faces of the remaining men are completely hidden - we may therefore hardly establish any sort of emotional relationship between the depicted characters. The protagonists of the scene are reduced to mutually isolated bodies; those bodies are not expressive bodies, but bodies closed off in privacy:

"[...] the figures in those canvases, mere representations, manifestly 'have' no interiority of the sort actual persons do. It is as if the zero for 'Expression' that de Piles brilliantly awarded Caravaggio simultaneously suggests doubts about whether expressions ever actually do reveal anything about the feelings or states of mind they are supposedly expressing and also suggests something about the inevitability of our taking even the lack of expression as revelatory.

Another, only slightly different way of framing the problem would be to say that the invention of absorption in Caravaggio's religious paintings of the late 1590 s and early 1600 s can be seen as in dialogue with the sceptical doubt that we can ever know with certainty the contents of another person's mind."

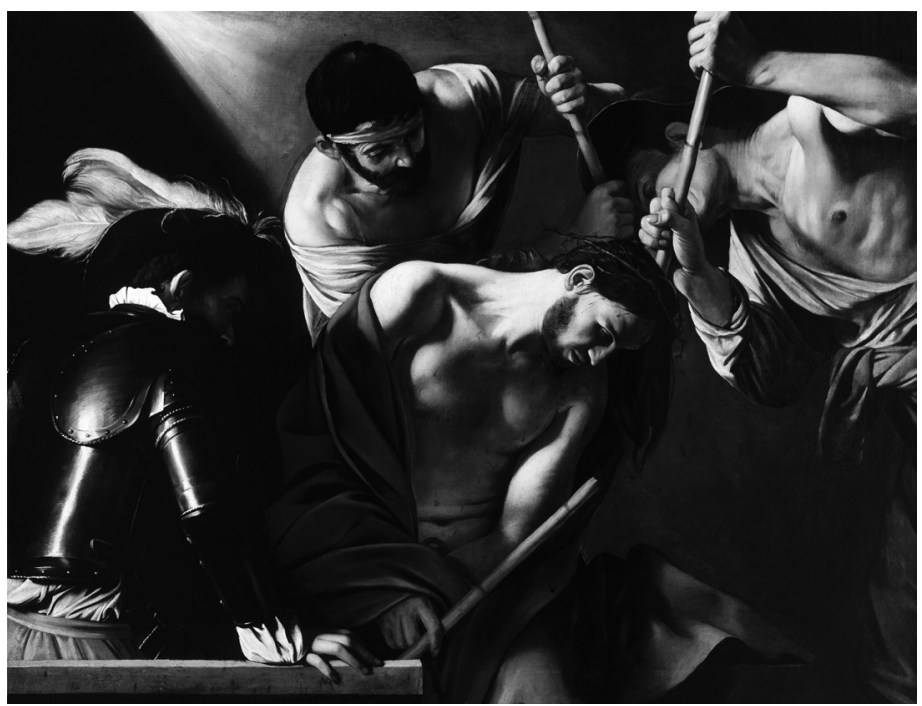


It is hardly surprising that a motive that appears time and again in Caravaggio's art is that of decapitation: a beheaded body is a radical annihilation of meaning, a definitive end of the criteria by which we think of the mind of another person; it exemplifies a body that does not matter anymore. A paradigmatic place is his Medusa of 1596-97: beheading becomes a radical form of scepticism. Equally important, the image was painted on a piece of canvas that was subsequently stretched over a round shield; there is no spatial depth whatsoever, no threedimensionality; from mimesis, the painting turns into an object, item, a flat surface, plane, or, as Fried calls it, a tableau. In other words, the painting becomes a 'special mental membrane' (to borrow the term from Slovenian art historian Tomaž Brejc, who used it in his interpretation of the modernist model of painting as a two-dimensional surface).

Caravaggio's treatment of the body is thus quite close to the way Wittgenstein problematized the body; namely, Wittgenstein wrote:

"I can perhaps even imagine (though it is not easy) that each of the people whom I see in the street is in frightful pain, but is artfully concealing it. And it is important that I have to imagine an artful concealment here. That I do not simply say to myself: 'Well, his soul is in pain: but what has that do to with his body?' or 'After all it need not show in his body!" ${ }^{5}$

Wittgenstein views the issue of pain as key for the problematic of philosophical scepticism. Scepticism about other minds concerns the problem of the (im) possibility of knowing the pain of another and thus also of knowing another person. The quoted passage points to the following question: what is the limit of our comprehension, knowing of the other and thus also of establishing a relation with that other? The Wittgensteinian answer is - the body. The body is the screen, barrier, limit, membrane that prevents us from reaching the other's 'interiority', their soul; the body is that membrane due to which we are always in danger of failing in terms of what Wittgenstein called the criterion of knowing another person. Or, as Cavell would say,

"To withhold, or hedge, our concepts of psychological states from a given creature, on the ground that our criteria cannot reach to the inner life of the creature, is specifically to withhold the source of my idea that living beings are things that feel; it is to withhold myself, to reject my response to anything as a living being; to blank so much as my idea of anything as having a body. To describe this condition as one in which I do not know (am not certain) of the existence of other minds, is empty. There is now nothing there, of the right kind, to be known. There is 
nothing to read from that body, nothing the body is of; it does not go beyond itself, it expresses nothing; it does not so much as behave. There is no body left to manifest consciousness (or unconsciousness). It is not dead, but inanimate; it hides nothing, but is absolutely at my disposal; if it were empty it would be quite hollow, but in fact it is quite dense, though less uniform than stone. It was already at best an automaton." ${ }^{\prime \prime}$

Caravaggio's art thus problematizes the crisis of the criteria that predicate language as an inter-social category; his art is the earliest example of what might be marked as 'art in the state of modernity'. Therefore, it is hardly surprising that, chronologically speaking, Caravaggio's art emerged in parallel with another form that reflected the collapse of a priori criteria - Shakespeare's drama. As Cavell shows, Shakespeare's tragedy is fundamentally linked with modern manifestations of sceptical doubt: his plots rest not on a force from 'beyond' that leaves the tragic subject powerless to govern his own fate, but precisely on the hero's isolation in a (Wittgensteinian) private language. Two typical examples are King Lear and Othello: in both plays, the plot emerges within dialectic of shame, that is, Lear and Othello's withdrawal before the gaze of the other and their need, in relating to another person, to demand an absolute, empirical proof of faithfulness. In Othello's own words, when he demands from Iago a material proof of Desdemona's infidelity:

Villain, be sure thou prove my love a whore,

Be sure of it. Give me the ocular proof

Or by the worth of mine eternal soul

Thou hadst been better have been born a dog

Than answer my waked wrath!

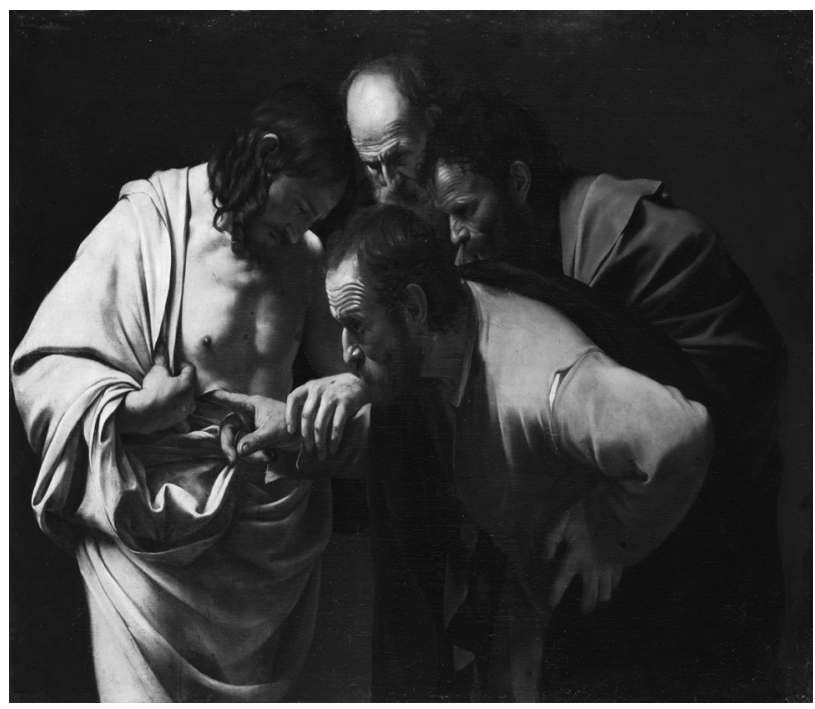


Their tragedy rests on their need to command perfect, ideal knowledge of the other person; since such knowledge is impossible, they both end up in radical scepticism, i.e. 'bad faith' that knowing the other as such is impossible. Shakespeare's tragedy thus precedes a new cultural, we might even say ideological paradigm that was also outlined by the philosophy of René Descartes, John Locke, and David Hume: knowledge rests on empirical evidence; if there is no such evidence, knowledge is impossible. That is precisely the reason why empiricism is inseparable from modern scepticism.

However, in Investigations, the body has a paradoxical status: the body is the cause of scepticism about the other, but at the same time, it is also the place where criteria are reconstituted, through that which Cavell labels as the 'capacity for exposure' to the gaze of the other. That means that the subject comes into being by mastering language and entering the space of inter-social communication, through a process that might be labelled the 'presentness' of the body. Moreover, the concept of presentness in Cavell's and Fried's theory bears a rather specific meaning - Cavell uses it to stress our capacity for establishing, faced with the gaze of the other, an inter-social relation with that same other; in that sense, presentness might mean visibility, presence, before other members of the polis; for instance, at the beginning of his first book on film, Cavell refers to Jean-Jacques Rousseau and uses his metaphor of the 'good city', that is, 'good spectacle'; the good city is a metaphor for a social relation in which I stand before others 'without shame'. ' Cavell thus uses the concept of presentness in opposition to that of shame: shame is a possible form of retreating before the gaze of the other, a sort of fantasy about a private language; shame is but my retreat into privacy, inside the boundaries of my body as a 'membrane', my attempt to annihilate meaning and suspend external criteria, my unconscious desire that my body not be a 'body that matters'. By contrast, presentness is a re-constitution of language's external criteria through the body, that is, a re-establishment of my relationship with other members of an inter-social community. In other words, presentness is my ability to recognise, by way of the body and language, another person made of flesh and blood, similar to myself, and let myself be recognised by that same other person; through presentness, we acknowledge "[...] our humanity - the fact that I and that you are human beings, and that we are fated to live with one another or reject one another."

This re-constitution of the criteria of language as an inter-social category, and realization of the presentness of work of art is the basic problem of art in the modern era. To describe this problem of artistic presentness, Cavell in 
his analysis of films uses the notions of 'dramatisation', i.e. 'transfiguration' of reality. Dramatisation points to the ability of films to transform the world and, even more so, to transform the human subject on the cinema screen; his argument is that the everyday world that surrounds us is so ordinary, mundane, banal, alienated from us, that we do not even notice it. Modern concept of art, but also of philosophy as given in Wittgenstein's, Austin's, Marx's or Heidegger's writings emerge as modern subject's reaction to the state of boredom, of losing interest for the world, alienation from the world, i.e. to the state of scepticism. This answer to the state of modern boredom or alienation is, according to Cavell,

"perhaps the most fruitful point of intersection of Anglo-American and Continental philosophizing. I mean the point concerning the issue of what is worth saying, the discovery that much of what is said, especially by philosophers, i.e., by the human being philosophizing is empty, say bankrupt, the result of speaking not meaninglessly, as the positivists used to like to say, as if words themselves had insufficient sense, but rather speaking pointlessly, as if we had nothing in mind, or nothing at heart to say."

The art of cinema emerges from our need to recreate the world in its image; as argued by Rothman and Keane, the world in its everyday existence, independently of the media of art, cannot satisfy this need we have. To satisfy our desire for the world, the medium of art must differ from the existing world, that is, film must transform (dramatise) the existing world into a world capable of satisfying our desire for the world. ${ }^{10}$ In other words, film must find a way to make the world it presents to us, as well as other people, persons shown on the screen, present; our response to the presentess of film is acceptance, recognition of that 'specifically human' in film, our empathy with the human subject on film, our acknowledgement of that subject, i.e. another person. In other words, film, art in the state of modernity and modern philosophy takes us back to the ordinary, everyday, to the language itself that due to the decomposition of a priori criteria that were characteristic for traditional societies became unknowable, invisible to us. Modern forms of art as cinema take us back, in words of Cavell, to our natural relation to existence which is "what Thoreau means by our being next to the laws of nature, by our neighbouring the world, by our being beside ourselves."11

It is therefore hardly surprising that modern film has established a specific link with Caravaggio's art; as Martin Scorsese put it, 
"I was instantly taken by the power of the pictures, the power of the compositions, the action in the frames... there was no doubt that it could be taken into cinema because of the use of light and shadow, the chiaroscuro effect [...] Initially I related to the paintings because of the moment that he chose to illuminate in the story [...] he was choosing a moment that was not the absolute moment of the beginning of the action, it's during the action, in a way. You sort of come upon the scene midway and you're immersed in it. It was very different from the composition of the paintings that precede it, the Renaissance paintings. It was like modern staging in film."12

In other words, Caravaggio's art, just like film today, dramatised reality; this is exactly the way Michael Fried reads Caravaggio's art as a far away predecessor of modernism. According to Fried, presentness of the work of art means elimination of narrativity, teatricality, its instantaneousness during the act of seeing. While older forms of art (renaissance for example, or classical staging of landscape in case of Claude Lorrain's painting, for example) needed complex ways to narrate the depicted scene - symmetrical arrangements of personages, or elaborate costumes, for example, Caravaggio depicts figures so engrossed or "absorbed in what they were doing, thinking, and feeling that they appeared oblivious of everything else, including, crucially, the beholder standing before the painting." Only in that way, through ignoring or denying of the beholder, painting accomplishes its ultimate purpose - it brings actual viewers to a halt "in front of the painting and holding them there in a virtual trance of imaginative involvement." In other words, Caravaggio needed new forms of visual representations, forms beyond mere visual storytelling of renaissance painting, he needed dark and light contrasts, extreme chiaroscuro, absorbtion, enlargements, corporality to make his painting convincing. With Caravaggio, very similar to later French painting from late $18^{\text {th }}$ century, but also to modernism, at every moment the work itself is wholly manifest:

"It is this continuous and entire presentness, amounting, as it were, to the perpetual creation of itself, that one experiences as a kind of instantaneousness, as though if only one were infinitely more acute, a single infinitely brief instant would be long enough to see everything, to experience the work in all its depth and fullness, to be forever convinced by it."13

This need of ours, as subjects, to dramatise our own existence is, in Cavell's and Fried's view, historically contingent: it emerged after the collapse of the meta-narratives of the religious view of the world and coincided with the 
birth of reason and modern rationality. This condition of modernity was later highlighted by the romantics and then also by Karl Marx, for instance: Marx's philosophy points to the fact that our place in society, in community, has become essentially unknown to us, that this place we occupy is marked by scepticism (Fried would say - by teatricality, Marx would say - by ideology). In modern society, human individuality emerges in isolation from other members of the polis. Self-cognition thus becomes primary to modern philosophy and art alike: it is possible only through the subject's relationship with the other, i.e. with the community, which is established by making our existence present in front of others. Caravaggio's paintings, Shakespeare's tragedies, romantic art, Marx's concept of revolution, and finally also the emergence of photography and film are only various manifestations of this need to dramatise, transfigure reality and realize presentness of the self. So what would be the art in the state of modernity? Well, nothing else but our attempt to give a voice to our scepticism - with regard to the world and other members of our community. 
Stephen Mulhall, "Stanley Cavell (1926-)”, in Art: Key Contemporary Thinkers, eds. Diarmuid Costello and Jonathan Vickery (Oxford and New York: Berg, 2007), 110-113.

Ibid.

Leo Bersani and Ulysse Dutoit, Caravaggio's Secrets (Cambridge, MA and London, UK: The MIT Press, 1998), 9.

Michael Fried, The Moment of Caravaggio (Princeton and Oxford: Princeton University Press, 2010), 103.

Ludwig Wittgenstein, Philosophical Investigations (Oxford: Blackwell Publishers, Ltd., 1999), 119 e.

Stanley Cavell, The Claim of Reason: Wittgenstein, Scepticism, Morality, and Tragedy (New York and Oxford: Oxford University Press, 1999), 88

Stanley Cavell, The World Viewed: Reflections on the Ontology of Film (Cambridge, MA: Harvard University Press, 1979), p. xxii. See also Nikola Dedić, 'Film i skepticizam: Kavelova "korekcija" poststrukturalističke filozofije umetnosti' (Film and Scepticism: Cavell's 'Correction' of Poststructuralist Philosophy of Art), Filozofija i društvo, Vol. XXVI, No. 1 (2015): 205-225.

Ludger H. Viefhues-Baily, Beyond the Philosopher's Fear: A Cavellian Reading of Gender, Origin and Religion in Modern Skepticism (Farnham, Surrey: Ashgate Publishing, 2007), 73.

Stanley Cavell, 'The Ordinary as the Uneventful', in Themes Out of School: Effects and Causes (Chicago and London: The University of Chicago Press, 1988), 184-194.

William Rothman and Marian Keane, Reading Cavell's The World Viewed: A Philosophical Perspective on Film (Detroit, MI: Wayne State University Press, 2000), 90.

Stanley Cavell, 'The Ordinary as the Uneventful'.

Andrew Graham-Dixon, Caravaggio: A Life Sacred and Profane (New York and London: W. W. Norton \& Company, 2010), 41-42.

Michael Fried, "Art and Objecthood", Art and Objecthood. Essays and Reviews (Chicago and London: The University of Chicago Press, 1998), 167. 
Bersani, Leo and Ulysse Dutoit, Caravaggio's Secrets. Cambridge, MA and London, UK: The MIT Press, 1998

Cavell, Stanley, 'The Ordinary as the Uneventful', in Themes Out of School: Effects and Causes. Chicago and London: The University of Chicago Press, 1988.

Cavell, Stanley, The Claim of Reason: Wittgenstein, Scepticism, Morality, and Tragedy. New York and Oxford: Oxford University Press, 1999.

Cavell, Stanley, The World Viewed: Reflections on the Ontology of Film. Cambridge, MA: Harvard University Press, 1979.

Dedić, Nikola, "Film i skepticizam: Kavelova "korekcija" poststrukturalističke filozofije umetnosti." (Film and Scepticism: Cavell's 'Correction' of Post-structuralist Philosophy of Art), Filozofija i društvo, Vol. XXVI, No. 1 (2015): 205-225.

Fried, Michael, "Art and Objecthood", Art and Objecthood. Essays and Reviews. Chicago and London: The University of Chicago Press, 1998.

Fried, Michael, The Moment of Caravaggio. Princeton and Oxford: Princeton University Press, 2010.

Graham-Dixon, Andrew, Caravaggio: A Life Sacred and Profane. New York and London: W. W. Norton \& Company, 2010

Mulhall, Stephen, "Stanley Cavell (1926-)." In Art: Key Contemporary Thinkers, eds. Costello, Diarmuid and Jonathan Vickery, 110-113. Oxford and New York: Berg, 2007.

Rothman, William and Marian Keane, Reading Cavell's The World Viewed: A Philosophical Perspective on Film. Detroit, MI: Wayne State University Press, 2000.

Vietfhues-Baily, Ludger H., Beyond the Philosopher's Fear: A Cavellian Reading of Gender, Origin and Religion in Modern Skepticism. Farnham, Surrey: Ashgate Publishing, 2007.

Wittgenstein, Ludwig, Philosophical Investigations. Oxford: Blackwell Publishers, Ltd., 1999. 


\section{ETIKA STANOVANJA: RANI HRIŠĆANSKI PRINCIPI GRADSKOG ŽIVOTA I URBANE TRANSFORMACIJE \\ Vladimir Mako}

Rad se fokusira na određeno pitanje u vezi etike koja se razvila u ranom hrišćanskom vremenu i njenog uticaja na proces transformacije rimskog urbanog života, navika, funkcije i arhitektonske prakse krajem petog veka i nakon toga.

Složenost ovog pitanja proizilazi iz činjenice da su rani hrišćanski monaški ideali, koji su se brzo razvili u prvim vekovima nove ere, značajno uticali na formiranje svakodnevnih životnih etičkih principa.

Shodno tome, ovi novi principi su promenili postojeće navike u stanovanju, posebno u oblasti javnog života, zahtevajući novi oblik ponašanja od hrišćanskih građana. Ovaj proces je uticao i na idealistički pogled na ono što koncept hrišćanskog grada može biti, i kako se novi oblik etičkog života odražava na nove urbane i arhitektonske strukture.

KLJUČNE REČI: ETIKA, ESTETIKA, GRADSKI ŽIVOT, URBANA TRANSFORMACIJA

\section{UMETNOST, MODERNOST I SKEPTICIZAM \\ Nikola Dedić}

Ovaj rad se bavi problemom odnosa umetnosti i modernosti - naša osnovna teza je da se umetnik u eri modernosti bavi problemom privatnosti. Pojam privatnosti se koristi u Vitgenštajnovom smislu, kao analogija njegovoj teoretizaciji fantazije privatnog jezika. Njegov koncept privatnog jezika je opis povlačenja običnog jezika iz procesa međudruštvenih odnosa i njegove svakodnevne upotrebe; na taj način, fantazija privatnog jezika je vrsta skepticizma. S obzirom na to da je pojam epistemološkog skepticizma povezan sa idejom modernosti (Dekartov, Hjumov, Lokov moderni skeptični predmet), glavni problem za savremenog umetnika je kako da prevaziđe stanje radikalnog skepticizma, odnosno uslov koji Stenli Kavel u Vitgenštajnovom smislu naziva 'metafizička izolacija'.

KLJUČNE REČI: UMETNOST, MODERNOST, SKEPTICIZAM, PRIVATNI JEZIK, OBIČAN JEZIK, LUDVIG VITGENŠTAJN, STENLI KAVEL

OD TRANSCENDENTALNOG IDEALIZMA DO TRANSCENDENTALNOG

EMPIRIZMA I ŠIRE: KANT, DELEZ I RAVNA ONTOLOGIJA UMETNOSTI Andrija Filipović

U ovom radu ću pokazati da pokret od Kantovog transcendentalnog idealizma do Žil Delezovog transcendentalnog empirizma, a zatim do novih materializma i spekulativnih realizma je ono što nam omogućava da razgovaramo o direktnom i ne-posredovanom pristupu stvari u sebi (ili njenom raspadanju). Drugim rečima, to je promena od uslova mogućeg iskustva do uslova realnog iskustva koja su omogućila trenutne filozofske i teorijske diskurse materializma i realizma. Ono što je od posebnog interesa za potrebe ovog rada je kako je promena od uslova mogućeg do stvarnog iskustva povezana sa trenutnom konceptualizacijom umetničkih praksi. Tačnije, ja ću pokazati kako se ontologija umetnosti promenila, ili barem da se možda čini da postoji mogućnost premeštanja paradigme različitih estetika i ontologija umetnosti, gde je ravna ontologija jedna od njih, sa pojavom novih materializma i spekulativnih realizma koji su omogućeni promenom u uslovima realnog iskustva.

KLJUČNE REČI: TRANSCENDENTALNI IDEALIZAM, TRANSCENDENTALNI EMPIRIZAM, RAVNA ONTOLOGIJA,

UMETNOST, KANT, DELEZ

IMPLIKACIJE VATIMOVOG VERWINDUNG-A MODERNIZMA

\section{U ARHITEKTONSKOJ TEORIJI}

\section{Vladimir Stevanović}

U postmodernom dobu, osim novog pristupa arhitektonskoj praksi, dešavaju se značajne promene u bavljenju arhitektonskim pisanjem i to zahvaljujući uplivu postmoderne transdisciplinarne teorije u arhitektonski diskurs. Arhitektonski teoretičari, kritičari i istoričari rado koriste doprinos 
filozofije, političkih nauka, sociologije, teorije umetnosti i književne kritike na polju kategorizacije i interpretacije postmodernih arhitektonskih stilova ili tendencija. Kako formalno-likovni aspekti prestaju da budu ekskluzivni faktor koji konstituiše stil ili tendenciju, dolazi do implementacije tema i paradigmi iz raznih postmodernih teorija, što dovodi do fenomena prevođenja teorije za arhitektonske potrebe. U većini slučajeva teorijski nazori služe kao pokriće u skladu sa kojim teoretičari arhitekture formulišu autorske poetike određenih arhitekata, proglašavaju poželjne modele recepcije njihovih arhitektonskih dela, i formiraju ukupne stavove prema disciplinarnom i društveno-istorijskom kontekstu. Međutim, postaje interesantno kada ista arhitektonska dela jednog ili više arhitekata bivaju na različite načine interpretirana od strane različitih arhitektonskih teoretičara. U tom smislu, rad sagledava ove premise na konkretnom primeru (1) u kome praksu čini Katalonska arhitektura osamdesetih, (2) u kome se ukrštaju ideje de Solà-Moralesa, Rosija i Fremptona, (3) a teorijski obrazac na koji se može fokusirati je Vatimov filozofski koncept Verwindung-a modernizma.

KLJUČNE REČI: VERWINDUNG, SLABA MISAO, MODERNIZAM, POSTMODERNIZAM, FUNDAMENTALIZAM, FRAGMENTARNOST

PITANJE PREDSTAVLJANJA I IDENTITETA IZMEĐU GLOBALIZMA I LOKALIZMA: SLUČAJ PAVILJONA HONG KONGA NA VENECIJANSKOM BIJENALU

\section{Eva Kit Vah Man}

Ovaj rad uzima umetničku instalaciju Li Kita izloženu u paviljonu Hong Konga na Bijenalu u Veneciji 2013. godine, kao studiju slučaja da ilustruje načine na koje dela nude i pomažu sačinjavanje izazvanog Hong Konga i subverziju agresivne i moćno rastuću Kine. Za razliku od 'očigledne' društvene kritike i 'grandioznog' izgleda umetničkih dela izloženih u kineskom paviljonu, Li Kitova umetnička instalacija - "impresionistička kuća” - u Hong Kongovom paviljonu ne samo da izgleda apstraktno, već i svetovno i čak i trivijalno. Pošto je umetnik bio izabran od strane organizatora bez učešća javnosti, ovo je generisalo žestoku javnu raspravu o reprezentativnosti 'Hongkongnosti' ove instalacije. Moja tvrdnja je da je ono što se čini trivijalnim i običnim u Lijevom radu predstavljeno da konstitutiše, a ne prikaže, umetnost nove generacije Hong Konga. To takođe može biti taktika manevarisanja političkim identitetom koji je nametnula Kina Hong Kongu svojim sveprisutnim i pritiskajućim prisustvom. Umetnost Hong Konga ima potencijal da se udalji ili da sumnja u velike narative Kine, da parafraziram reči istoričara umetnosti Dejvida Klarka (1997). Verujem da je motiv međunarodne konferencije "Hong Kong kao metod" decembra 2014. na Univerzitetu u Hong Kongu bio da upotrebom očekivanog destabilizuje i ospori hongkonški "zdravo-za-gotovo" politički identitet i na taj način promoviše raznolikosti i međuazijsku kulturnu dinamiku.

KLJUČNE REČI: UMETNOST INSTALACIJA, HONGKONGNOST, KINESKOST, POLITIKA IDENTITETA, GLOBALIZAM

SAVREMENA KINESKA UMETNOST:

MAOVO NASLEĐE I DANTOOVA DEFINICIJA

Mary Bittner Wiseman

U ovom radu pokušala sam da izvedem tri stvari. Kao prvo, da identifikujem nekoliko tema $\mathrm{u}$ savremenoj kineskoj umetnosti kroz koje pokazuje svoju suštinski socijalna prirodu i svoj robustan materijalizam, karakteristike kojih nema često u zapadnoj umetnosti. Drugo, da ukažem da način na koji je savremena umetnost u Kini postmoderna jete način na koji je i zapadna umetnost, i da potkrepim tvrdnju da koliko god da su teme i nedavna istorija ove umetnosti drugačije od zapadnog pandana, ova umetnost zadovoljava definiciju umetnosti koju je konstruisao Artur Danto, a to je ona koja na fino zaokružuje i širinu i dubinu koncepta umetnosti. Konačno, u poslednjem delu, predstaviću rad jedne žene-umetnika koji se razlikuje od većine skorašnjih kineskih radova i tipičnih radova zapadne umetnost. On se pozicionira na marginama onoga što je umetnost u Kini i što Dantoova definicija obuhvata, istovremeno sugerišući srž umetničke prakse i jedan od načina biti žena. 